\title{
A Variation of Phrenic Nerve: Case Report and Review
}

\author{
Una Variación del Nervio Frénico: Reporte de Caso y Revisión \\ "Prakash; "Latha V. Prabhu; "Jwalaram Kumar; "Sampath Madhyastha \& ** Gajendra Singh
}

PRAKASH; PRABHU, L. V.; KUMAR, J.; MADHYASTHA, S. \& SINGH, G. A variation of phrenic nerve: Case report and review. Int. J. Morphol., 24(4):689-690, 2006.

SUMMARY: During routine dissection in the Department of Anatomy following anatomical variations of phrenic nerve were observed on right side in the neck region of a middle aged cadaver. The phrenic nerve in its early course close to its origin was giving a communicating branch to $\mathrm{C} 5$ root of brachial plexus and at the level of the root of neck just before entering the thorax, the phrenic nerve was placed anterior to the subclavian vein. This unique case of phrenic nerve variation gains tremendous importance in context of subclavian vein cannulation, implanted venous access portals, and supraclavicular nerve block for regional anesthesia.

KEY WORDS: Phrenic nerve; Neck; Anatomical variations.

\section{INTRODUCTION}

Variations of phrenic nerve have been observed and reported in past (Anson \& McVay, 1971; Hollinshead, 1982 and Bergman et al., 1988). Right subclavian vein cannulation is commonly performed procedure for vascular access for hemodialysis and the phrenic nerve palsy manifesting as hemidiaphragmatic paralysis is an important complication associated with it (Islek et al., 1998, Porzionato et al., 2003, Akata et al., 1997, DNetto et al., 2001, Agrawal et al., 2000). Right phrenic nerve paralysis is acknowledged immediate and late complication of implanted venous access portals (Reeves \& Anderson, 2002]. Bigeleisen (2003) reported a case of simultaneous diaphragmatic and brachial plexus stimulation followed by a successful nerve block and demonstrated the necessity of a thorough knowledge of anatomical variations and standard anatomy for the safe and efficientpractice for regional anesthesia.

\section{CASE REPORT}

The following important variations were observed only on the right side during routine dissection in a middle aged male cadaver. Phrenic nerve in its early course close to its origin, was giving a communicating branch to $\mathrm{C} 5$ root of brachial plexus. The phrenic nerve at the level of root of neck just before entering the thorax was placed infront of the subclavian vein. Usually it is placed posterior in between subclavian vein and artery.

Aforementioned variation of phrenic nerve makes it highly vulnerable to injury during subclavian catheterization for vascular access.

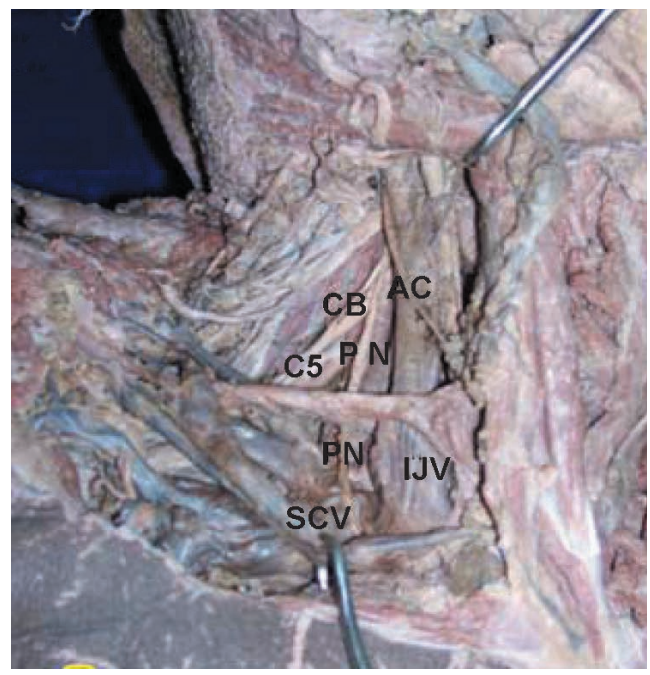

Fig. 1.Variations of Phrenic nerve. AC. Ansa cervicalis; CB. Communicating branch to brachial plexus; C5. C5 root of brachial plexus; PN. Phrenic nerve; IJV. Internal jugular vein; SCV: Subclavian Vein.

\footnotetext{
* Department of Anatomy, Kasturba Medical College, Mangalore, Karnataka, Pin: 575004, India.

${ }^{* *}$ Department of Anatomy, Institute of Medical Sciences, Banaras Hindu University, Varanasi, U. P., Pin: 221 005, India.
} 


\section{DISCUSSION}

Accessory phrenic nerve proceeds caudally and joins distally with phrenic nerve and is present in upto $75 \%$ of cadavers (Bigeleission, 2003). On the contrary in this particular case the communicating branch from phrenic nerve to C5 root of brachial plexus proceeded proximally and medially in cephalic direction and joined the phrenic nerve.

Hollinshead described that the entire phrenic nerve in 10 out if $138(7.25 \%)$ sides of cadavers studied passed anterior to subclavian vein as it leaves the neck. Whereas in the present case this particular variation of phrenic nerve was accompanied further by a retrograde communicating branch from $\mathrm{C} 5$ root of brachial plexus. Bigeleission reported that more distal blocks, such as a low interscalene or supraclavicular block, may also give rise to a partial phrenic nerve block, even if the phrenic nerve anatomy is standard. Aforementioned context in the present case will lead to complete phrenic nerve block manifesting as right diaphragmatic paralysis.

Embryological hypothesis: The guidance of the developing axons is regulated by expression of chemoattractants and chemorepulsants in highly coordinated site specific fashion. Any alterations in signaling between mesenchymal cells and neuronal growth cones can lead to significant variations which probably in the present case resulted in phrenic nerve communication with $\mathrm{C} 5$ root of brachial plexus along with subclavian vein placed posterior to phrenic nerve. Once formed, any developmental differences would persist postnatally (Sannes et al., 2000).

PRAKASH; PRABHU, L. V.; KUMAR, J.; MADHYASTHA, S. \& SINGH, G. Una variación del nervio frénico: Reporte de caso y revisión. Int. J. Morphol., 24(4):689-690, 2006.

RESUMEN: Durante una disección de rutina en el Departamento de Anatomía, observamos una variación anatómica del nervio frénico en el lado derecho del cuello de un cadáver de mediana edad. El nervio frénico cercano próximo a su origen dio un ramo comunicante para la raíz C5 del plexo braquial. A nivel de la raíz del cuello, justo antes de entrar al tórax, el nervio frénico se colocaba anterior a la vena subclavia. Este caso único de variación del nervio frénico adquiere una gran importancia en caso de canulación de la vena subclavia, implantes venosos accesos portales, y bloqueo del nervio supraclavicular por anestesia regional.

PALABRAS CLAVE: Nervio frénico; Cuello; Variación anatómica.

\section{REFERENCES}

Agrawal, S.; Hari, P.; Bagga, A. \& Mehta, S. N. Phrenic nerve palsy: a rare complication of indwelling subclavian vein catheter. Pediatr. Nephrol., 14(3):203-4, 2000.

Akata, T.; Noda, Y.; Nagata, T.; Noda, E. \& Kandabasi, T. Hemidiaphragmatic paralysis following subclavian vein catheterization. Acta. Anesthesiol. Scand., 41(9):1223-5, 1997.

Anson, B. J. \& McVay CB. Surgical Anatomy. $5^{\text {th }}$ ed. W.B. Saunders Company, Philadelphia, 286, 1971.

Bergman, R. A.; Thompson, S. A.; Afifi, A. K. \& Saddeh, F. A. Copendium of Human Anatomical Variation. Urban and Schwarzenburg, Baltimore, 138-9, 1988.

Bigeleisen, P.E. Anatomical variations of the phrenic nerve and its clinical implication for supraclavicular block. $B r . J$. Anaesth., 91(6):916-7, 2003.

D’Netto, M. A.; Bender, J.; Brown, R.T. \& Herson, V. C. Unilateral diaphragmatic palsy in association with a subclavian vein thrombus in a very-low-birth weight infant. Am. J. Perinatol., 18(8):459-64, 2001.

Hollinshead, W. H. Anatomy for Surgeons, The head and neck. Third ed. Harper and Row Publishers, New York, 1982.
Islek, I.; Akpolat, T. \& Danaci, M. Phrenic nerve palsy caused by subclavian vein catheterization. Nephrol. Dial. Transplant., 13:1023-5, 1998.

Porzionato, A.; Montisci, M. \& Manani, G. Brachial plexus injury following subclavian vein catheterization: A case report. J. Clin. anesth., 15 (8):582-6, 2003.

Reeves, J. E. \& Andeson, W. F. Permanent paralysis of the right phrenic nerve. Annals of Inter. Med., 137(6):551-2, 2002.

Sannes, H. D.; Reh, T. A. \& Harris, W. A. Development of nervous system In: Axon growth and guidance. New York, Academic Press, 189-97, 2000.

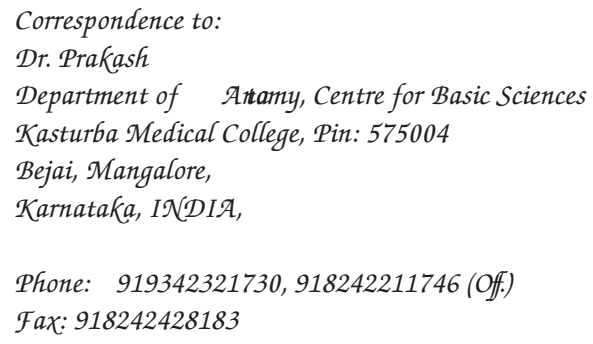

